\title{
Equilibrium
}

Quarterly Journal of Economics and Economic Policy

VOLUME 7 ISSUE 2, 2012

ISSN 1689-765X

\author{
Monika Grebíková* \\ Brno University of Technology, Czech Republic
}

\section{The EfFect of TaX Changes ON FinANCial LEASING IN THE CZECH REPUBLIC}

\section{JEL Classification Codes: $G 3$}

Keywords: fixed assets, financial leasing, income tax, VAT, tax changes

\begin{abstract}
The article is focused on fixed assets, especially on purchase by financial leasing. There are summarized tax changes of income tax and VAT. The main aim of the article is to find out the legal framework and to analyze the effect of the tax changes on financial leasing in the Czech Republic.
\end{abstract}

\section{INTRODUCTION}

The paper concentrates on fixed assets, mainly on decisions about purchase and finance. The main attention is paid to purchase of fixed assets by financial leasing. There are summarized all important changes in Income tax act (Act No. 586/1992) and Value added tax law (Act No. 235/2004). The aim of the paper is to analyze the consequences of the tax changes on financial leasing in the conditions of the Czech Republic.

(C) Copyright Nicolaus Copernicus University Press

Date of Submission: February 27, 2011; date of acceptance: May 30 , 2012

* Contact: e-mail: grebikova@fbm.vutbr.cz, Vysoké učení technické v Brně, Fakulta podnikatelská, Kolejní 2906/4, 61200 Brno, Czech Republic 


\section{THE LEGAL FRAMEWORK OF FIXED ASSETS}

The following rules are dedicated to the issue of the fixed assets, the way of their acquisition and financing:

- Act No. 586/1992 (Income tax act),

- Act No. 563/1991 (Accounting directives law),

- Act No. 235/2004 (Value added tax law),

- The public notice No. 500/2002, which shall be made to certain provisions of Act No. 563/1191 (Accounting directives law),

- The measure No. 281/89 759/2001, laying down the procedures and chart of accounts for the entrepreneurs.

The Czech legal standards distinguish three basic types of fixed assets, intangible assets, tangible assets and financial assets.

Intangible fixed assets must have a service life longer than one year (from the date of their acquisition) and the costs have to be higher than 60000 CZK. The service life means the period during which the assets are available for current or future use. Among intangible fixed assets there are e.g.: established expenditures, intangible results of research and development, software, valued rights and so on.

The total costs of acquisition a tangible fixed asset (movable) has to be higher than $40000 \mathrm{CZK}$ and its service life has to be longer than one year. Tangible fixed assets include e.g.: land, buildings, non-residential premises, work of art, the basic herd and draught animals, etc.

Long-term financial assets, according to $\S 8$ of public notice No. 500/2000, are for example: shares in the business unit (in a daughter company), long-term debt securities (held to maturity), long-term loans and credits, etc. (Jaroš 2010, pp. 33-63), (Public notice No. 500/2002, Act No. 235/2004)

\section{METHODS OF ACQUISITION AND FINANCING OF FIXED ASSETS}

Acquisition of the fixed assets can be carried out by the followings ways:

- by purchase,

- by creating in own activities of the entrepreneur (,capitalization of fixed assets"),

- by acquisition of property for free (e. g. donation),

- by contribution of fixed assets by another subject,

- by transfering property from personal use to business, 
- by acquisition of rights from the results of intellectual creative activities. (Jaroš 2010, pp. 38-44).

Entrepreneurs who decide for acquisitions of fixed assets have to solve the problem of funding the assets. The available options are following:

- cash purchase,

- purchase on credit,

- lease-purchase agreement. (Valouch 2009, pp. 17-19).

Each of the above mentioned options has some advantages and disadvantages and entrepreneurs have to be very careful while making a decision about acquisition.

Purchase of assets in cash is based on the assumption that the entrepreneur has enough available funds, which can be used for the acquisition of the assets. The most important fact, from the perspective of entrepreneurs, is that immediately after the purchase the entrepreneur becomes the owner. That is the moment when entrepreneurs get the unrestricted rights to dispose of the object, which is included in the assets. This method of acquisition does not run entrepreneurs into the debt. On the other hand, it is possible to observe a negative impact on cash flow, because of the large single expenditure in cash.

If the entrepreneurs do not want to finance the acquisition of fixed assets from their own resources (cash purchase), another options could be used e.g. credit or leasing.

The purchase of assets on credit has several uncontested advantages. First of them is the fact that, comparing to cash purchase, the entrepreneur does not need a large amount of available funds from his own resources at the moment of the purchase. Another huge plus of this method is also the fact that thanks to a bank credit the entrepreneur becomes the owner immediately at the time of purchase. Hence the purchase it is possible to apply the tax write-offs, which are eligible from the income tax act (if they meet the conditions defined in the Act No. 586/1992). The entrepreneurs may also use the tax recognition of interests on the bank loan (if it meets the condition in $\$ 24$ article 2 (zi) of the income tax act).

The main disadvantages of bank credits are especially the obligation to pay interests of the loans at regular times and the high fees which the banks charge without any significant difference among them. Usually, the processing of application for a loan is not free of charge. The bank credit belongs to the foreign resources, which negatively affects the degree of indebtedness. The above mentioned facts are summarized in the following definition: "The great advantage of purchase on credit is the fact that the ownership of the assets is transferred to the buyer immediately at the moment of signing the agreement. The owner gets the rights to 
dispose with the assets and these rights are not limited in any way" (Valouch 2009, p.20).

It should be mentioned that Czech legislation recognizes two basic forms of lease, the financial leasing and the operational leasing.

Operational leasing is a form of the current lease, which is realized on the basis of signed contract. The lessee gives up an item for a benefit of the leaseholder in return of payment. The object of leasing has to be in good conditions for the use defined in the contract. The leaseholder is allowed to use the object of lease and to take benefits from it. Operational leasing is based on the assumption that after the end of the lease the object of leasing will be returned to the lessee (Valouch 2009, pp. 17-19).

Financial leasing is usually a longer-term lease. The leasing contract contains information that the leaseholder is authorized to buy the object of leasing during or at the end of lease term. The transfer of ownership to the object of leasing is provided by a separate contract between lessee and leaseholder.

From the above mentioned definitions of various forms of leasing, it is possible to define an important technical difference. The main difference is that the leaseholder becomes only renter "a temporary" in the financial leasing. At the end of lease term, the ownership of object is transferred from the lessee to the leaseholder. While in the operational leasing the lease of the object is only temporary. After the agreed period of lease the object of leasing still belongs to a leasing company. There is no change of ownership.

In the following part of the article the attention will be concentrated only on financial leasing. Financial leasing has a big plus due to the fact that on a day of purchase it is not necessary to have a large amount of available funds. The rent for financial leasing is divided into a longer period. The rent is, according to the Czech income tax act ( $\$ 24$ article 2 and $\S 24$ article 4 ), eligible tax expenditure, and therefore reduces the tax base. Because the leasing rent enters the costs gradually, the financial leasing does not increase the total indebtedness of the company. It would seem that financial leasing is clearly the best way, but this way of acquisition assets has also some drawbacks...The main drawback is the leasing ownership of the object. The asset, which is the object of the leasing contract, remains in the ownership of the lessee during the whole lease term. The lessee can draw the entitlement to tax write-offs on the object of leasing, so after the repurchase by the leaseholder the object of leasing is fully depreciated. Moreover, the leaseholder takes all risks associated with the ownership (e.g. the risk associated with the destruction or theft of the object of leasing). Also, any modifications on the object of leasing are possible only with consent to the lessee. And finally, of course, it is very difficult to cancel leasing contracts... (Valouch 2009, pp. 33-38, Act No. 586/1992). 
In the following table, the most important advantages and disadvantages of the various ways of financing the acquisition assets are summarized.

Table 1. Summary of the advantages and disadvantages of various ways of financing assets

\begin{tabular}{|c|c|c|}
\hline $\begin{array}{l}\text { The method of } \\
\text { financing }\end{array}$ & The advantages & The disadvantages \\
\hline Cash purchase & $\begin{array}{l}\text { Not increasing the total indebted- } \\
\text { ness } \\
\text { A buyer becomes immediately the } \\
\text { owner } \\
\text { No restriction (unrestricted rights } \\
\text { to dispose with the asset) }\end{array}$ & Negative impact on cash flow \\
\hline $\begin{array}{l}\text { Purchase } \\
\text { on credit }\end{array}$ & $\begin{array}{l}\text { Need a smaller quantity } \\
\text { of available funds from own } \\
\text { resources at the moment of pur- } \\
\text { chase } \\
\text { The entrepreneur becomes the } \\
\text { owner at the moment of purchase } \\
\text { The entrepreneur may apply the } \\
\text { tax write-offs } \\
\text { Tax eligibility of paid interests }\end{array}$ & $\begin{array}{l}\text { Obligation to pay interests } \\
\text { Fees for operation of the credit } \\
\text { accounts } \\
\text { Fees for processing of application } \\
\text { Increase of the total indebtedness }\end{array}$ \\
\hline $\begin{array}{l}\text { Lease-purchase } \\
\text { agreement }\end{array}$ & $\begin{array}{l}\text { The rent is divided into a longer } \\
\text { period } \\
\text { The rent is tax expenditure } \\
\text { Leasing does not increase the total } \\
\text { indebtedness }\end{array}$ & $\begin{array}{l}\text { The owner of the object for whole } \\
\text { lease term is the lessee } \\
\text { The leaseholder cannot draw an } \\
\text { entitlement to tax write-offs } \\
\text { The leaseholder takes all risks } \\
\text { associated with the ownership } \\
\text { Any modification on the object of } \\
\text { leasing only with consent } \\
\text { of the lessee } \\
\text { Difficulty to cancel leasing con- } \\
\text { tracts } \\
\text { Danger to withdraw the object of } \\
\text { leasing }\end{array}$ \\
\hline
\end{tabular}

Source: Own processing based on sources: Hovorka (2010); Jaroš (2010, pp. 33-63), Valouch (2007); Valouch (2009, pp. 17-38).

\section{LOAN VS. LEASING}

Each of the above mentioned ways of financing assets has its own advantages and disadvantages. When deciding about the method of acquisition of the asset on loan or by leasing it is necessary to pay attention to the three key areas: 
Administrative intensity and the right to free dispose of assets

Leasing is very popular in the Czech Republic. One of the reasons may be the fact, that it is an administratively less demanding way of acquisition assets. Leasing companies meet customers' halfway e. g.: leasing for means of transport comprise directly into the leasing contract damage liability and time to time also accident insurance (with better conditions than usual). „The great advantage of leasing is its small administrative intensity and also additional services provided by the leasing companies with more favourable conditions than is common on the market" (Valouch 2009, pp. 20).

\section{Tax implications}

On the base of income tax act, the fees are associated with conclusion and operation on the bank credits and leasing contracts recognized as tax expenditure. The same situation is with a rent of tangible assets, that the leaseholder has to pay to the leasing company. Both the leaseholder and the lessee have the obligation to distinguish the rent between current and future perio. In the case of intangible assets, the situation is a little bit different. The income tax act allows a leaseholder and a lessee at the same time to write off the object of leasing ( $\$ 32 \mathrm{a}$ article 3 of income tax act).

\section{The financial intensity of acquisition assets}

The main attention belongs to the real cash flows, which entrepreneurs have to spend during the leasing or credit relationship. For determination of the financial intensity of acquisition the asset it is possible to use the "net benefits of leasing" method. It compares the net present value of investment financed by leasing and loan (Valouch 2009, pp. 19-25).

$$
\check{C} V L=K-\left(\frac{\sum_{n=1}^{N} L_{n} \times(1-d)+\sum_{n=1}^{N} d \times Q_{n}}{(1+i)^{n}}\right)
$$

Where: $\check{C} V L=$ net benefits of leasing; $K=$ capital expenditure; $L_{n}=$ leasing payments in each of the years of service life; $d=$ tax rate; $O_{n}=$ tax write-offs each of the years of service life; $n=$ a year of service life; $N=$ service life; $i=$ interest rate including the effect of income tax (Valouch 2009, pp. 19-25). 


\section{FINANCIAL LEASING FROM \\ THE PERSPECTIVE OF ACT NO. 586/1992 (INCOME TAX ACT)}

In Act No. 586/1992 (Income tax act), considerable attention is paid to financial leasing. The great danger of financial leasing in terms of the income tax act is that the tax conditions defined in this law (§ 24 article 2(h)) have to be complete. Otherwise, the rent paid, which was originally eligible for tax purposes, may backward become the rent, which is not eligible for tax purposes. Of course, it is connected with a danger of fiscal penalties, the interest on overdue payment and fines, which the revenue authority can award to the tax subject.

Great attention is paid to the issue of financial leasing in $\$ 24$ of income tax act, especially in $\S 24$ article $2(\mathrm{~h})$, articles 4,5 and 6, and also in articles 15 and 16). It is necessary to emphasize that all business units, if they want to be in accordance with the Act No. 563/1991, have to distinguish between the current and future expenditures. For this reason, a "costs of future periods" account appears in the accounting of leaseholders and in the accounting of lessee appears a "deferred income" account, which allows business units to fulfill this obligation.

The income tax act does not recognize the concept of "financial leasing". For the purposes of the Act No. 586/1992, financial leasing is defined as "financial lease with future purchase of the rented tangible assets".

There have been significant changes in the issue of financial leasing in the last years. For the determination of the conditions for tax eligibility of lease installments it is necessary to know the time of the conclusion of the leasing contract. (Brychta et all 2010, pp. 473-489), (Jaroš 2010, pp. 77-80, Act No. 586/1992)

The summary of the most important changes in the financial leasing from the perspective of the income tax act (Act No. 586/1992) is processed in the Table 2.

Additional conditions to accept the lease installments as tax expenditures are defined in $\S 24$ article 4 (b). This section says that immediately after the end of the lease a transfer of ownership to object of leasing has to follow from the lessee to the leaseholder. While the purchase price of object of leasing (tangible assets) shall not be higher than the net book value calculated from the entry price by using linear depreciation defined in $\S 31$ article 1 (a) of income tax act to the date of sale. If this "fictional" tax net book value was zero, this condition could not be made. 
Table 2. The most significant changes in the financial leasing from the perspective of Act No. 586/1992 (Income tax act)

\begin{tabular}{|c|c|}
\hline $\begin{array}{l}\text { Contract is conclud- } \\
\text { ed: }\end{array}$ & $\begin{array}{l}\text { According to the Act No. } 586 / 1992 \text { (income tax act), lease } \\
\text { installments aretax expenditure, if: }\end{array}$ \\
\hline $\begin{array}{c}\text { Until } \\
31^{\text {st }} \text { December } 2007\end{array}$ & $\begin{array}{l}\text { The lease term is longer than } 20 \% \text { of the amortization period } \\
\text { defined in } \$ 30 \text { of income tax act, at least } 3 \text { years (for movable } \\
\text { assets) and for real estate at least } 8 \text { years. }\end{array}$ \\
\hline $\begin{array}{c}\text { From } \\
1^{\text {st }} \text { January } 2008 \\
\text { until } \\
31^{\text {st }} \text { March } 2009\end{array}$ & $\begin{array}{l}\text { The lease term of tangible movable assets is at least the same } \\
\text { as the minimum of amortization period defined in } \$ 30 \text { article } 1 \\
\text { of income tax act and in the case of real estate at least } 30 \\
\text { years. }\end{array}$ \\
\hline $\begin{array}{l}\text { From } 1^{\text {st }} \text { April } 2009 \\
\quad \text { until } \\
31^{\text {st }} \text { December } 2010\end{array}$ & $\begin{array}{l}\text { For tangible movable asset, which (according to supplement } \\
\text { No. } 1 \text { of income tax act) belongs to: } \\
- \text { The } 1^{\text {st }} \text { depreciation group lasts at least } 36 \text { months, } \\
- \text { The } 2^{\text {nd }} \text { depreciation group lasts at least } 54 \text { months, } \\
- \text { The } 3^{\text {rd }} \text { depreciation group last at least } 114 \text { months, } \\
- \text { Real estate lasts at least } 30 \text { years. }\end{array}$ \\
\hline $\begin{array}{c}\text { From } \\
1^{\text {st }} \text { January } 2011\end{array}$ & $\begin{array}{l}\text { The lease term of tangible movable assets shall be at least the } \\
\text { minimum of amortization period defined in } \$ 30 \text { article } 1 \text {; for } \\
\text { tangible movable assets which belong to the } 2^{\text {nd }} \text { or } 3^{\text {rd }} \text { depreci- } \\
\text { ation group according to supplement No. } 1 \text { of income tax act, } \\
\text { the lease term can be shortened up to } 6 \text { months. The lease term } \\
\text { of real estate has to last at least } 30 \text { years. }\end{array}$ \\
\hline
\end{tabular}

Source: own processing based on sources: Brychta et all (2010, pp. 473-489); Jaroš (2010, pp.77-80); Valouch (2009, pp. 27-39); Act No. 586/1992.

The last condition for tax eligibility of the lease installments is laid down in $\S 24$ the article 4 (c). After the end of financial lease with future purchase of the rented tangible assets the entrepreneur from $\S 2$ (natural person) has to include the repurchased asset (object of leasing) to his business property.

In the conclusion of the financial leasing in the period from $20^{\text {th }}$ July 2009 to $30^{\text {th }}$ June 2010, if the conditions in $\$ 24$ article 15 of income tax act are fulfilled, the lease term can last 12 months (for assets in the $1^{\text {st }}$ depreciation group) or 24 months (for assets in the $2^{\text {nd }}$ depreciation group). These special conditions in accordance with the income tax act are:

- The lessee (leasing company) is allowed to use "extraordinary depreciation" according to $\S 30 \mathrm{a}$ of income tax act,

- The lessee is the first owner of a "new" asset,

- The lessee bought the asset (the object of leasing) in the period from $1^{\text {st }}$ January 2009 to $30^{\text {th }}$ June 2010. (Brychta et all 2010, pp. 473-489, Act No. 586/1992). 


\section{FINANCIAL LEASING \\ FROM THE PERSPECTIVE \\ OF ACT NO. 235/2004 (VALUE ADDED TAX LAW)}

From the perspective of value added tax law there is a similar problem as in the case of income tax act. To determine the correct VAT rate it is necessary to know the date of conclusion of the contract of financial leasing. The VAT rate for financial leasing was significantly changed to $1^{\text {st }}$ May 2004; because this is the day the Czech Republic joined the European Union.

Until $30^{\text {th }}$ April 2004 the VAT was governed by the Act No. 588/1992. According to $\S 16$ was the base rate of VAT intended on $22 \%$ and decreased rate of VAT on 5\%. The financial leasing belonged according to $\S 28$ article 1 (c) to "financial activities", so it was covered by the provisions of $\S 16$ article 5 and the decreased rate of VAT could be used.

The Act No. 588/1992 was replaced by a new Act No. 235/2004 on $1^{\text {st }}$ May 2004. The new VAT law had a fundamental impact on the lessees of financial leasing. Compared with the Act No. 588/1992 applicable to $30^{\text {th }}$ April 2004, the new VAT law was much worse for the lessees. The majority of taxable fulfillment (including lease relations, which were not exempted from VAT), was moved from the decreased rate to the base rate of VAT= $19 \%$. This fact greatly increased the price of financial leasing. The impact was reflected especially in the financial leasing of passenger cars.

The legal adjustment of VAT, which was valid until $31^{\text {st }}$ December 2008, considered individual lease installments as "a partial fulfillment". It meant that individual lease installments were charged of VAT $\Rightarrow>$ each payment was a separate tax base. The lessee paid VAT from individual lease installments and the leaseholder could exercise the entitlement on VAT deduction directly from the individual lease installments. The tax document was a schedule of payments. In this form, it was valid until $31^{\text {st }}$ December 2008.

According to the amendment of the VAT law, valid from $1^{\text {st }}$ January 2009, financial leasing was not the partial fulfillment any more. Financial leasing has been considered as "a delivery of goods" or "a conveyance of real estate" from the date of origin the right to use the object of leasing. With that, of course, new obligations to lessees and leaseholders were related. The lessee had the obligation to pay VAT newly from the total leasing price immediately at the beginning of the contract. The total leasing price included:

- extraordinary installment,

- lease installments,

- the selling price. 
The leaseholder can exercise the entitlement on VAT deduction immediately at the beginning of the contract, of course, only for commodities allowed by the law (e. g. the entitlement on VAT deduction was not for leasing of passenger cars). The tax document was not the schedule of payment, but newly only the invoice.

This amendment to the VAT law touched contracts which were concluded after $1^{\text {st }}$ January 2009, and all contracts signed to $31^{\text {st }}$ December 2008, for which the takeover of the object of leasing was in 2009.

From $1^{\text {st }}$ April 2009 the amendment of Act No. 235/2004 (VAT law) has come in force, which repealed the provisions laid down in $\S 75$ article 2 . It contained the prohibition of VAT deduction when purchasing a passenger car. From $1^{\text {st }}$ April 2009 it was possible to use VAT deduction for passenger cars purchased in the Czech Republic, acquired from another state of EU, or imported from third countries. The tax deduction was allowed if the place of fulfillment was in the Czech Republic and the date of taxable fulfillment was not before $1^{\text {st }}$ April 2009. The conditions for entitlement to the deduction of the VAT were defined from $\S 72$ to $\$ 79$. Very important was the fact that for passenger cars acquired until $31^{\text {st }}$ March 2009 were not the entitlements of the deduction of the VAT also after the $1^{\text {st }}$ April 2009. (Act No. 235/2004; Act No. 588/1992; Finance... 2009; Živnostník 2009).

\section{THE DEVELOPMENT OF FINANCIAL LEASING IN THE CZECH REPUBLIC}

In 2002, according to international statistics, the goods the total amount of 3.4 billion euro were acquired in by financial leasing, which is much more than in Poland and Russia, thus in countries with a much larger market. Entrepreneurs preferred leasing, especially because getting the bank loan was too lengthy (Hovorka 2010).

In the "golden times" for the leasing companies in the Czech Republic, leasing was used primarily for the purchase of passenger cars. In the year 2000, passenger cars represented a share of $48.5 \%$ of all movable assets which were financed by leasing. In 2010, it was only $25.5 \%$ of movable assets. The reason could be the economic crisis and the associated decline in the willingness to take loans, but especially natural structural changes. (ČLFA 2006; ČLFA 2011).

Currently, the published statistics show that the Czech Republic follows a trend typical for the countries of Western Europe. Entrepreneurs are gradually moving from leasing to bank credits. This trend is influenced by the economic recession and also by the fact that at the beginning of the transformation period entrepreneurs did not have any history in their banks. 
Nowadays they have a history, so they are more trustworthy partner than they were before (Hovorka 2010).

From the statistic published by the Czech leasing and financial association (ČLFA), it is possible to see that the financial leasing is less and less used for the purchase of utility cars (vans). The share of leasing of utility cars in the total volume of leasing of movable assets represented $19.9 \%$ in 2007 , while in 2010 , it was only $4.2 \%$.

Exactly the opposite trend is for the purchase of ships, planes, wagons and engines. In 2007, the share of these commodities constituted $1.2 \%$. In 2010, it was already $5.0 \%$ of the total volume of the leasing of movable assets.

What is very interesting is also the one-year fluctuation in the item "machines and equipment" in 2009. In 2009 compared to 2008 increased the share of the item by more than $6 \%$.

In the statistics of ČLFA, a new item ("photovoltaic equipment") has appeared since 2010 . The item immediately got a share of the total financial leasing of movable assets 18.3\%. (ČLFA 2006; ČLFA 2011).

Chart 1. The leasing of movable assets in the Czech Republic according to the commodities in 2007 (share of the total volume in \%)

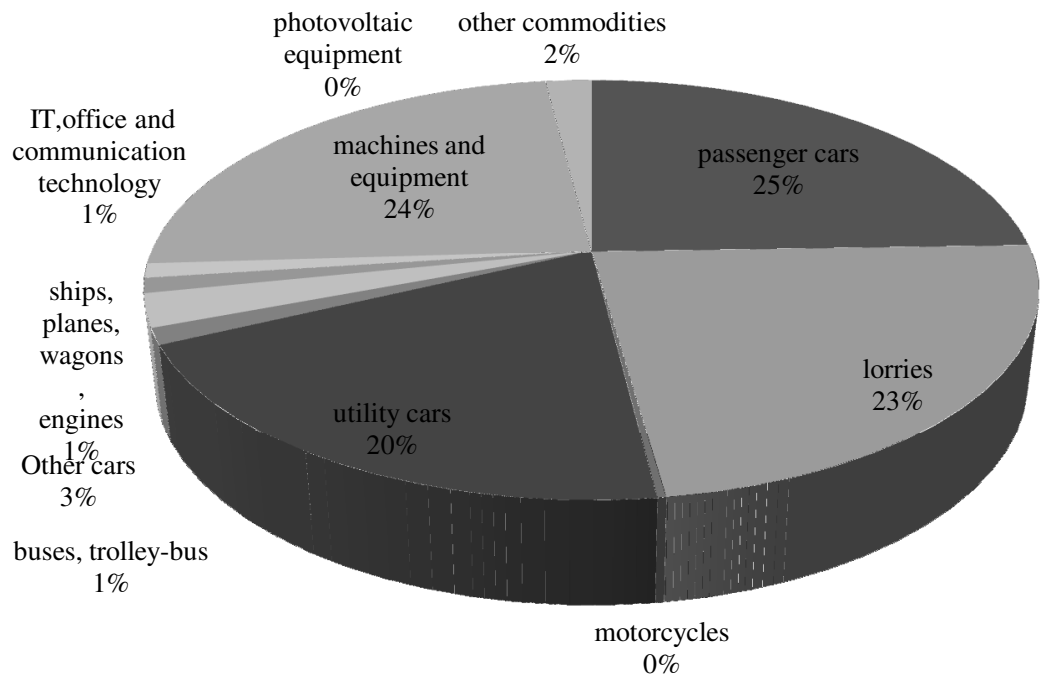

Source: Czech leasing and financial association (2011). 
Chart 2. The leasing of movable assets in the Czech Republic according to the commodities in 2008 (share of the total volume in \%)

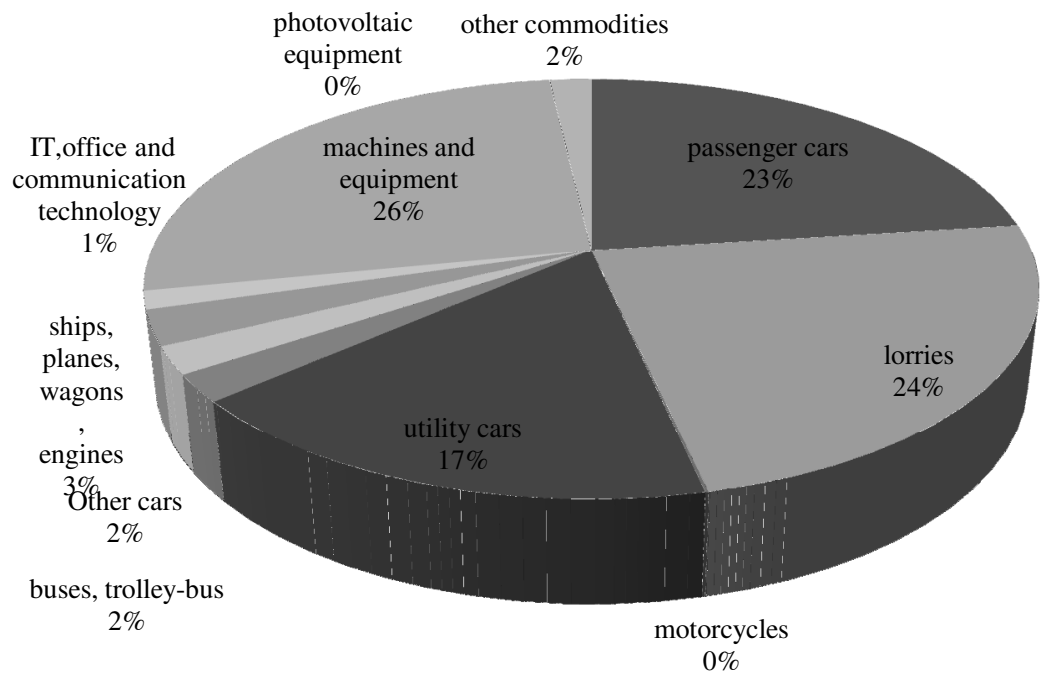

Source: Czech leasing and financial association (2011).

Chart 3. The leasing of movable assets in the Czech Republic according to the commodities in 2009 (share of the total volume in \%)

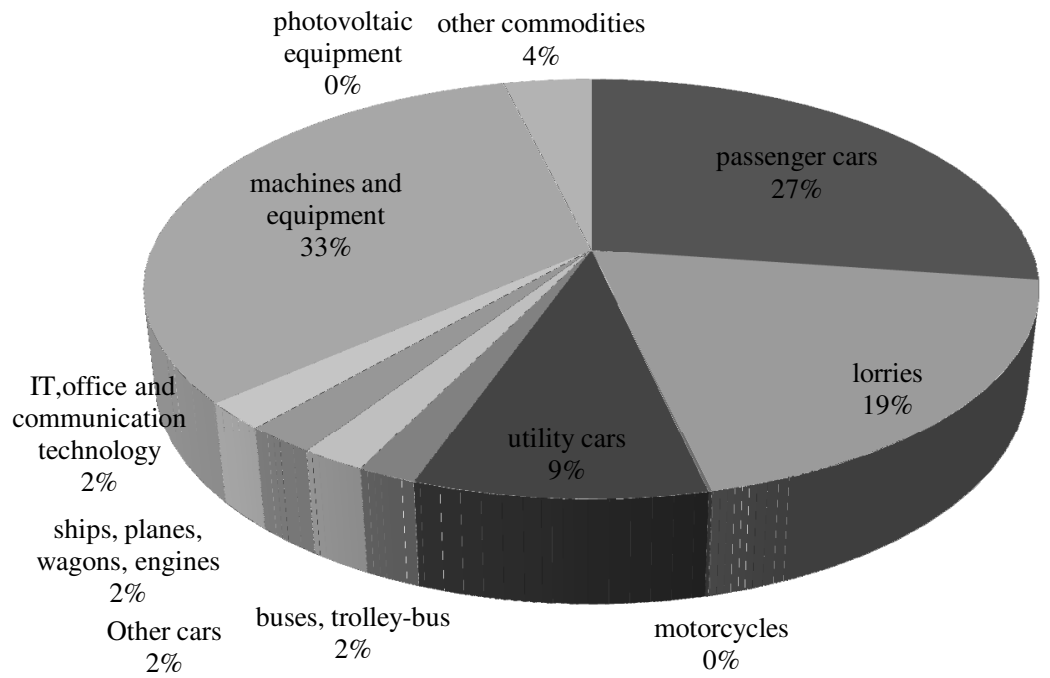

Source: Czech leasing and financial association (2011). 
Chart 4. The leasing of movable assets in the Czech Republic according to the commodities in 2010 (share of the total volume in \%)

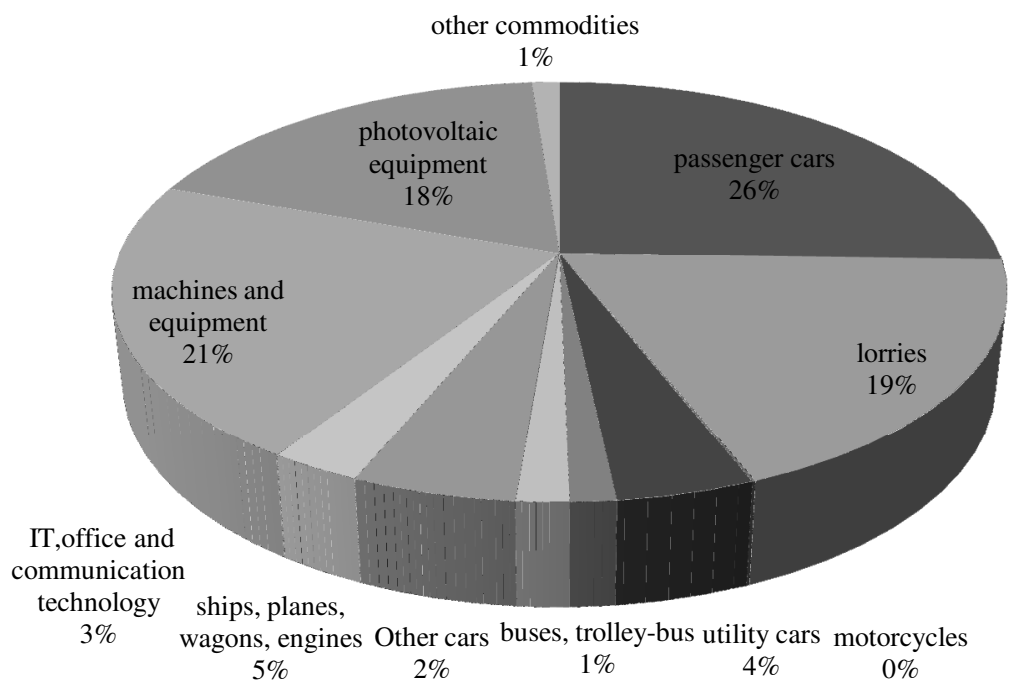

Source: Czech leasing and financial association (2011).

\section{THE STATITICS OF THE LEASING OF MOVABLE ASSETS ACCORDING TO SECTORS OF THE ECONOMY}

From the statistics published by the Czech leasing and financial Association (further just ČLFA), it is possible to observe the development in the use of leasing of movable assets according to sectors of the economy.

While in 2000 the private consumers represented a share of 17\% of the total leasing movable assets, in 2010 their share decreased to a mere $3 \%$.

The sector "industry, building industry" increased the share from $25 \%$ in 2000 to $37.5 \%$ in 2010 .

The highest share in the period (from the year 2000 to the year 2010) had "services private sector", which retains approximately $50 \%$ of the total volume of movable assets (ČLFA 2006; ČLFA 2011). 


\section{Monika Grebíková}

Chart 5. Leasing of movable assets according to sectors of the economy in 2000 (share in \%)

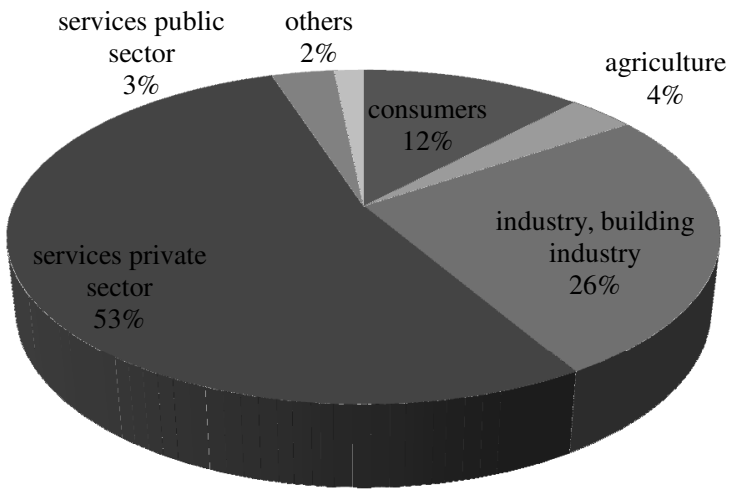

Source: Czech leasing and financial association (2006).

Chart 6. Leasing of movable assets according to sectors of the economy in 2007 (share in \%)

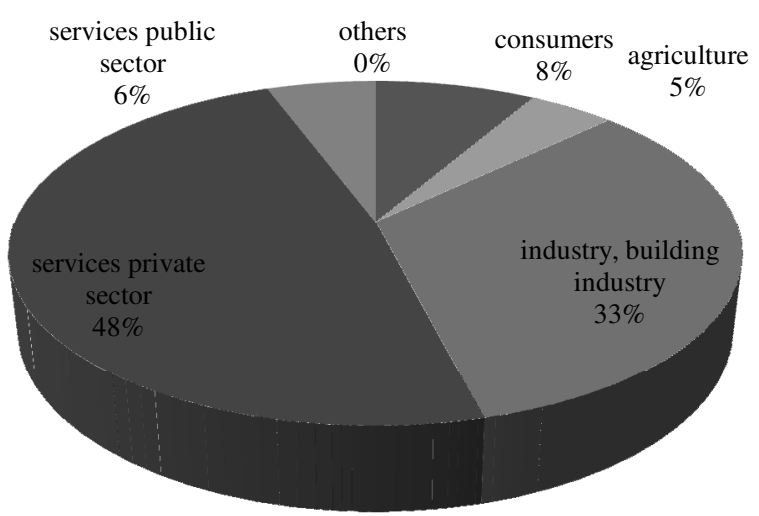

Source: Czech leasing and financial association (2011). 
Chart 7. Leasing of movable assets according to sectors of the economy in 2008 (share in \%)

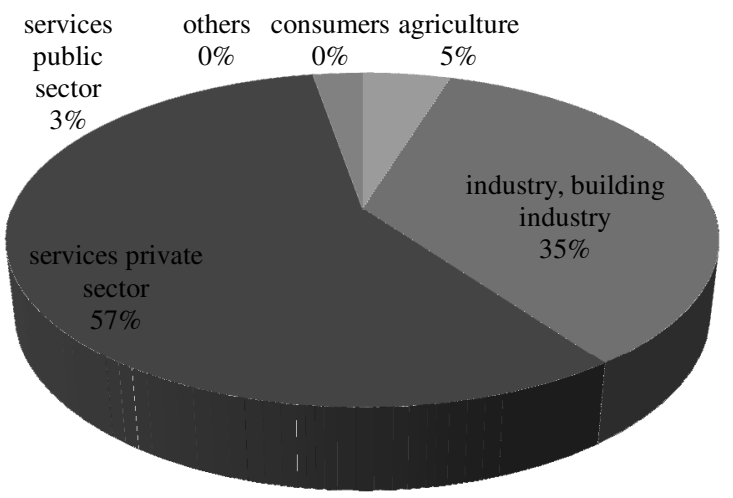

Source: Czech leasing and financial association (2011).

Chart 8. Leasing of movable assets according to sectors of the economy in 2009 (share in \%)

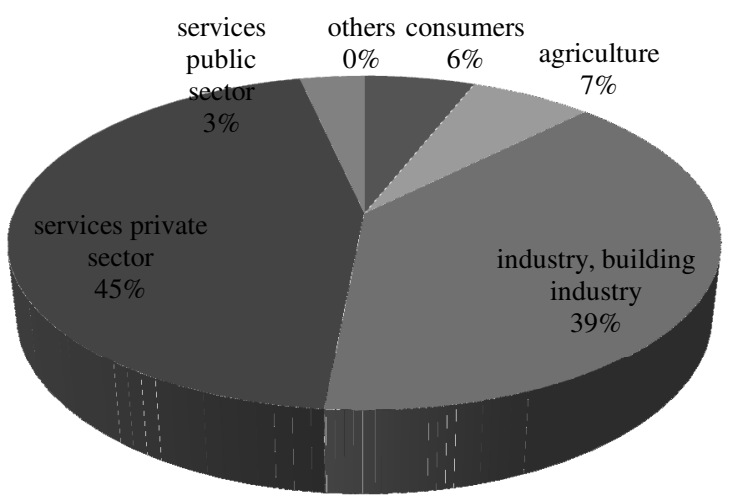

Source: Czech leasing and financial association (2011). 
Chart 9. Leasing of movable assets according to sectors of the economy in 2010 (share in \%)

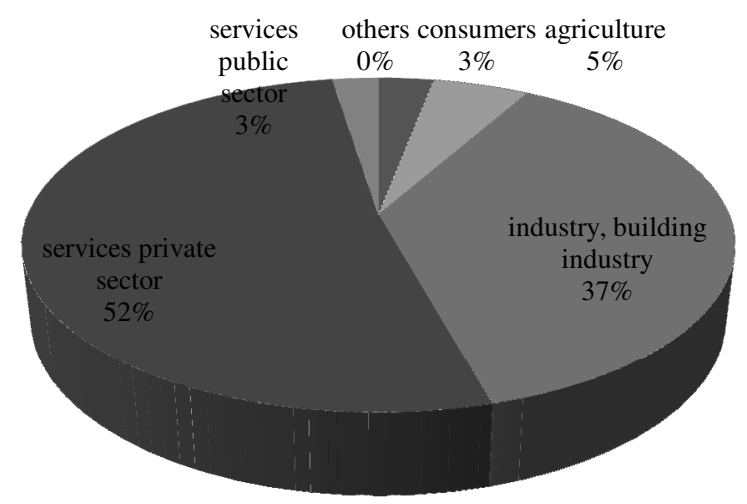

Source: Czech leasing and financial association (2011).

\section{THE STATISTICS OF FINANCIAL LEASING IN THE CHECH REPUBLIC FROM THE YEAR 2000 UNTIL 2010}

It is possible to see from the published statistics that the leasing of movable assets had the upward trend from 2000 until 2004. In 2004, there was a slight decrease compared to the year 2003. The decrease may have been due to the change of VAT rate for financial leasing. However, in the following years (from 2005 until 2007) the lessees of financial leasing managed very well. The decline of interest in financial leasing came in 2008 and continued in 2009. In 2010, there was a slight improvement, but in comparison with volume of leasing of movable assets in 2007, when the interest in financial leasing reached its peak, it is relatively low. The situation was probably caused by the changes in the income tax act. The Amendment of the Act No. 586/1992 changed the minimum compulsory duration of leasing tangible movable assets. This fact could have significantly affected the interest of financial leasing, primarily from the point of view of entrepreneurs.

The financial leasing of real estate had a gradual increase of volume from 2000 until 2004, in the upcoming years the reached level was kept. Statistics of ČLFA shows a radical decline in the interest of financial leasing in 2009. It fell by almost $75 \%$ compared to leasing of real estate in 2008 . This decline continued also in the following year and it was probably caused by the amendment of the income tax act. The amendment valid from 1st January 
2008 substantially extended the minimum compulsory duration of financial leasing, from 8 to 30 years. (ČLFA 2006; ČLFA 2011; Act No. 235/2004; Act No. 586/1992).

Chart 10. The growth of financial leasing by members of ČLFA (in billions CZK)

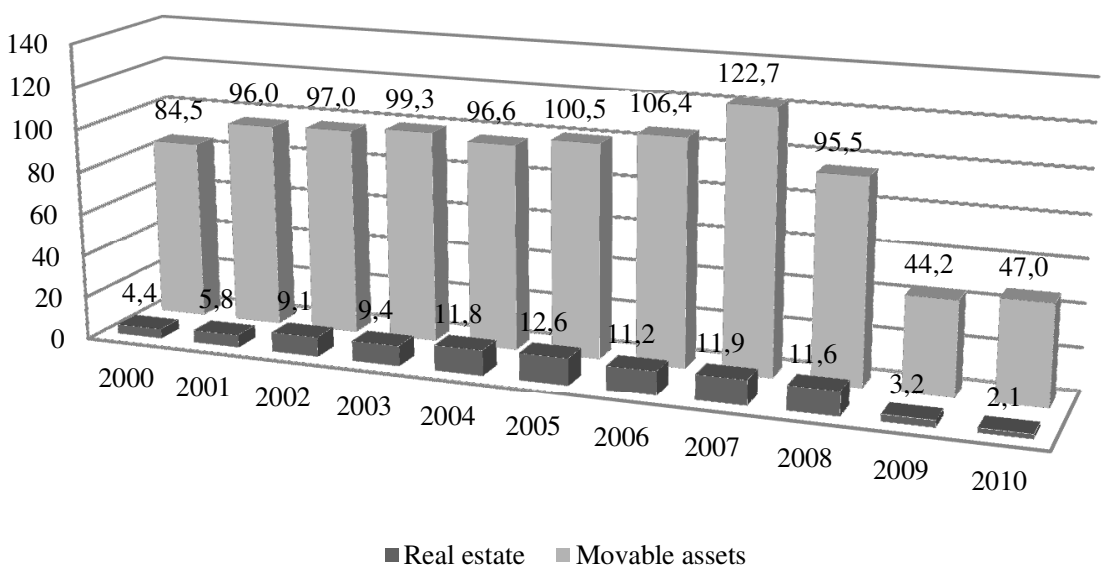

Source: Czech leasing and financial association (2011).

\section{THE DEVELOPMENT OF FINANCIAL LEASING ABROAD}

On the basis of statistics published by Leaseurope, which associates leasing association operating in the territory of the European Union, it was found that also in other states of the EU there has been a decline in interest of financial leasing. The trend began in 2008, when the total volume of newly concluded leasing decreased by more than 26.299 million euro, compared to 2007. An even greater decline came in 2009, when the volume of newly concluded leasing recorded the greatest decline almost 100 million EURO in comparison with the previous year.

The declining share of the newly concluded leasing was negatively reflected in the values of the total volume of the leasing. In 2008, the total volume of leasing of members of the association Leaseurope, reached its record level of 732.735,21 million euro. In 2009, there can be 


\section{Monika Grebíková}

observed a decrease of more than 47.089 million euro in comparison with the year 2008 (Leaseurope 2010).

Chart 11. The development of the total volume of leasing by members of Leaseurope from 2006 until 2009 (in millions EURO)

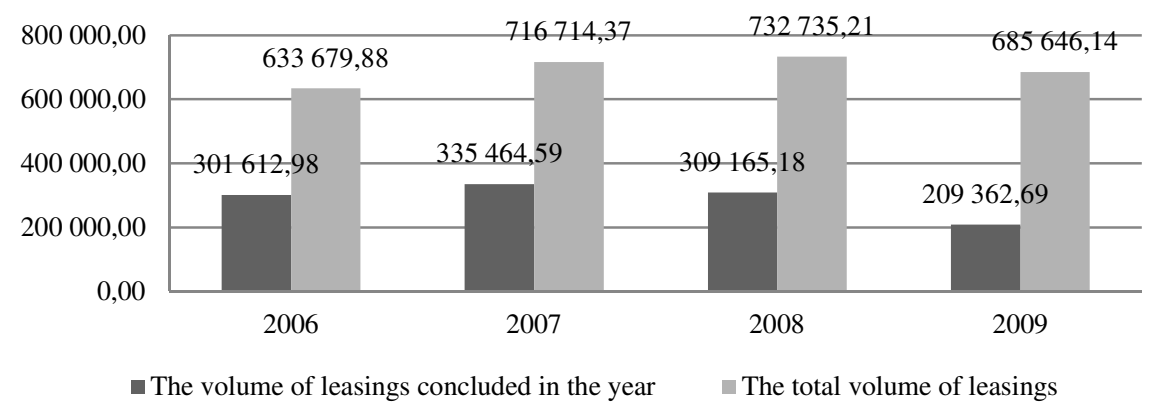

Source: Leaseurope (2010).

The trend of a slight decrease of the total volume of leasing can be monitored especially in Western European countries. To confirm the above mentioned statement the following countries were chosen: Germany, Spain, France and Italy.

Chart 12. The total volume of leasing by selected members of Leaseeurope between the years 2006 and 2009 (in millions EURO)

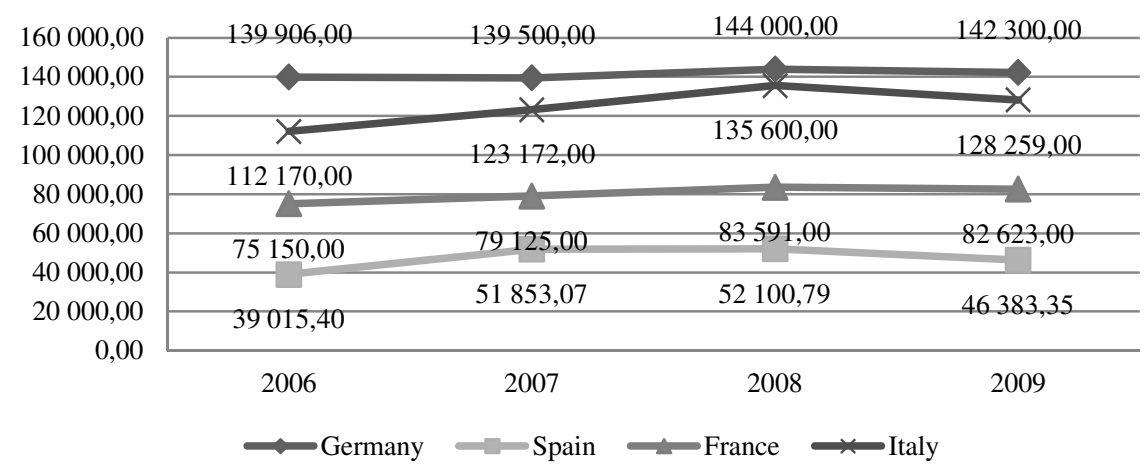

Source: Leaseurope (2010) . 


\section{CONCLUSIONS}

The major impact of changes in Act No. 235/2004 (VAT law) on the volume of leasing movable assets appeared in 2004. On $1^{\text {st }}$ May 2004 the Czech Republic became a member of European Union. It was connected with large changes in VAT and financial leasing was moved from the decreased rate of VAT $(5 \%)$ to the base rate $(19 \%)$. The change resulted in the increase of price of financial leasing for customers and the interests of these services decreased. As a result of the above mentioned facts, the volume of leasing decreased about 2.7 billion CZK in 2004 in comparison with 2003.

According to the Income tax act (Act No. 586/1992), valid from $1^{\text {st }}$ January 2008 , entered into force a change which significantly ex-tended the minimum duration of financial leasing of movable assets compared to the previous years. Entrepreneurs quickly responded to the change, and it caused a decrease of the total volume of leasing of movable assets. In 2008, there was a reduction of 27.2 billion CZK compared to 2007. The trend continued also in 2009, when there was a further substantial decline of the volume of leasing. In 2009, the volume of leasing decreased by even more than 51 billion CZK compared to 2008. The amendment of the income tax act caused the extension of the minimum duration of financial leasing of real estate too. Until $31^{\text {st }}$ December 2007 the minimum duration of leasing of real estate was 8 years, from $1^{\text {st }}$ January 2008 the minimum duration has been changed to 30 years. In 2008, the volume of leasing of real estate remained at the same level as in the previous years, but the radical decline came in 2009. It was a decline of 8.4 billion CZK, so the total volume of leasing of real estate decreased from 11.6 billion CZK to 3.2 billion CZK.

Another problem for leasing companies was the amendment of VAT law valid from $1^{\text {st }}$ January 2009. Until $31^{\text {st }}$ December 2008 the lease installments were "partial fulfillment". Since $1^{\text {st }}$ January 2009 the lease installments have become a "delivery of goods" or "conveyance of real estate". The amendment resulted in obligation to pay VAT immediately at the beginning of lease. This change has caused a radical decline of the volume of leasing of movable assets, by more than $1 / 2$ compared to the year 2008 .

The changes of Income tax act and VAT law were not only negative from the perspective of financial leasing there were also some positive aspects. The amendment of VAT law, which entered into force on $1^{\text {st }}$ April 2009, allowed the deduction of VAT for passenger cars. The amendment should encourage entrepreneurs and especially the car industry in the Czech Republic in the times of economic crisis. Thanks to this change, the share of passenger cars increased on the total volume of leasing of movable assets from $23.0 \%$ in 2008 to $27.3 \%$ in 2009 in the Czech Republic. 
The slight decrease in the interest of financial leasing can be observed also in some Western European countries. It can be affected by the economic crisis and by the entrepreneurs' fear of the future.

On the basis of the analysis, it is possible to confirm the assumption that changes in tax laws have a significant impact on the use of financial leasing in practice. The assumption can be proved by the Act No. 235/2004 (VAT law) and the Act No. 586/1992 (Income tax act).

The main aim of the further research will be a creation of a model using fuzzy logic, which will be able to manage the tax liability of entrepreneurs by using various ways of acquiring the assets.

\section{LITERATURE}

Act No. 235/2004 (Value added tax law).

Act No. 563/1991 (Accounting directives law).

Act No. 586/1992 (Income tax act).

Act No. 588/1992 (Value added tax law valid until $30^{\text {th }}$ April 2004).

Brychta I. (2010), Daň z př́jmů 2010, [in:] Dergel M. (ed.), Daň z př́ijmů 2010, Woters Kluwer ČR, Praha.

ČLFA (2011), Zpráva o stavu a vývoji nebankovního leasingového, úvěrového a faktoringového trhu $v \check{C} R$, http://www.clfa.cz/index.php?textID=64 (14 February 2011).

ČLFA (2006), Statistiky ČLFA (2000-2006), http://www.clfa.cz/index.php?text ID $=66\left(14^{\text {th }}\right.$ February 2011 $)$.

Finance.cz (2009), Leasing podle nového zákona o DPH, http://www.finan cninoviny.cz/os-finance/leasing/zpravy/leasing-podle-noveho-zakona-o-dph/356 72 (2 March 2011).

Hovorka J. (2010), Je leasing mrtvý?, http://www.mesec.cz/clanky/je-leasing-mrtvy/ (7 February 2011).

Jaroš T. (2010), Dan̆ z príjmů právnických osob v účetnictví 2009/2010 praktický pri̊vodce, GRADA Publishing, Praha.

Leaseurope (2010), Leasing Fact \& Figurek 2009, http://www.leaseurope.org/index. php?page=key-facts-figures (5 March 2011) .

Leaseurope (2010), Leaseurope Statistics, http://www.leaseurope.org/index.php ?page $=$ stats-surveys $\left(5^{\text {th }}\right.$ March 2011).

Measure No. 281/89 759/2001, laying down the procedures and chart of accounts for the entrepreneurs.

Pevný T. (2002), Leasing nebo úvěr?, http://www.mesec.cz/clanky/leasing-nebouver/ $\left(7^{\text {th }}\right.$ February 2011$)$.

Public notice No. 500/2002, which shall be made to certain provisions of Act No. 563/1191 (Accounting directives law).

SGEF.cz. (2008), Hlavní změny zákona o DPH s účinností od 1.1.2009 a jejich vliv na finanční leasing, http://www.sgef.cz/web/sgef/sgef-web2_cz_cz.nsf/Inhalt/ zmeny_DPH\#2008 ( $4^{\text {th }}$ March 2011). 
Valouch P. (2009), Leasing v praxi-praktický průvodce, GRADA Publishing, Praha.

Valouch P. (2007), Koupit majetek na úvěr nebo využít leasing? Jak se rozhodnout správně, http://finance.idnes.cz/koupit-majetek-na-uver-nebo-vyuzit-leasing-jakse-rozhodnout-spravne-121-/uver.asp?c=A070406_163035_fi_osobni_vra $\quad\left(8^{\text {th }}\right.$ February).

Živnostník.cz (2009), Uplatňování nároku na odpočet DPH u osobnych automobili̊, http://www.zivnostnik.cz/1/1/uplatnovani-naroku-na-odpocet-dph-u-osobnich-au tomobilu-cid213447/ ( $2^{\text {nd }}$ March 2011). 
